Івано-Франківський національний медичний університет

\title{
ПЕРЕДДИПЛОМНА ПРАКТИКА 3 АКУШЕРСТВА ТА ГІНЕКОЛОГІЇ СТУДЕНТІВ КОЛЕДЖУ ЗА СПЕЦІАЛЬНІСТЮ “ЛІКУВАЛЬНА СПРАВА” ТА ЕФЕКТИВНІСТЬ ЇЇ ПРОВЕДЕННЯ
}

\author{
I. P. Polishchuk
}

\section{Ivano-Frankivsk National Medical University \\ EXTERNSHIP IN OBSTETRICS AND GYNECOLOGY FOR COLLEGE STUDENTS IN THE SPECIALTY OF GENERAL MEDICINE AND ITS EFFECTIVENESS}

\begin{abstract}
Мета роботи - покращити умови професійного розвитку та набуття компетентності майбутніх випускників коледжів шляхом залучення до проходження переддипломної виробничої практики.

Основна частина. Проведення переддипломної практики у медичних навчальних закладах України є важливим етапом у формуванні студента фельдшера-акушера. У наведених даних наявні свідчення про першовартісність набутого практичного досвіду під час проходження переддипломної виробничої практики з акушерства-гінекології у студентів 4 курсу коледжу за спеціальністю “Лікувальна справа”. Викладено основні методики, що застосовуються в процесі навчання, наведено переваги та моменти, що потребують обговорення. Аналіз такого підходу до підготовки майбутніх спеціалістів вказує на можливість розширення їх професійної компетентності із бажанням залишитися в спеціальності.

Висновок. Переддипломна практика фельдшерів дозволяє у реальності застосувати набуті під час навчання знання та отримати досвід, мати почуття відповідальності за досягнуті результати; здатність учитися на помилках, забезпечити високу професійну підготовку фахівців - професійну компетентність.
\end{abstract}

Ключові слова: переддипломна практика; викладання акушерства і гінекології; професійна компетентність; фельдшер-акушер.

The aim of the work - to improve the conditions of professional development and acquisition of competence of future college graduates by engaging in pre-graduate practice.

The main body. Externship practice in medical educational institutions of Ukraine is an important stage in the formation of an obstetrician student. In the given data there is evidence of firsthand experience gained during the pre-graduate internship practice in obstetrics and gynecology at the 4th year students of the college in the specialty of Medical Business. The main methods used in the learning process are described, and the advantages and points that need to be discussed are presented. An analysis of such an approach to the training of future specialists indicates the possibility of expanding their professional competence with the desire to remain in the specialty.

Conclusion. The externship of the physician assistant in obstetrics and gynecology allows to apply knowledge acquired during learning process and gain experience and sense of responsibility for results. It provides the ability to learn from mistakes and to provide high professional training of specialists - professional competence.

Key words: externship; teaching of obstetrics and gynecology; professional competence; physician assistant in obstetrics and gynecology.

Вступ. Сьогодні перед середньою медичною освітою стоїть найважливіше завдання - забезпечити високу професійну підготовку фахівців, тому що якість медичної допомоги безпосередньо залежить від рівня підготовки випускників медичних коледжів. У теперішній час організація навчального процесу здійснюється з метою підвищення якості освіти фахівців і забезпечення на цій основі конкурентоспроможності випускників та престижу

(C) І. П. Поліщук української середньої медичної освіти у світовому освітньому просторі. Віковий розвиток людини, як суб’єкта праці, включає, на думку фахівців, три етапи: допрофесійного розвитку; розвитку в період вибору професії; розвитку в період професійної підготовки та подальшого становлення професіонала. Останній із наведених етапів охоплює декілька стадій: професійної підготовки; адаптації молодого спеціаліста до умов праці; майстра [8]. У період професійної підготовки відбувається навчання 
молодої людини у спеціалізованому навчальному закладі. При цьому особливістю навчально-професійної діяльності студента є їі спрямованість на оволодіння засобами, методами розв'язання тих проблем і завдань, що виникатимуть у ході його подальшої роботи після закінчення навчального закладу [8].

Мета роботи - покращити умови професійного розвитку та набуття компетентності майбутніх випускників коледжів шляхом залучення до проходження переддипломної виробничої практики.

Основна частина. Проведення виробничої практики студентів медичних та фармакологічних навчальних закладів I-II рівня акредитації, затвердженої наказом МОЗ України від 7 грудня 2005 року № 690, є важливим етапом у формуванні та становленні майбутніх фельдшерів-акушерів. На особливу увагу заслуговує той факт, що даний вид практики є першим самостійним кроком студентамедика в стаціонарі.

Мета проведення переддипломної практики після завершення 4 курсу студентів зі спеціальністю “Лікувальна справа” полягає в закріпленні практичних навичок у межах цілей, визначених в освітньо-професійній програмі підготовки фахівця. Виробнича практика студентів 4 курсу в обсязі професійних обов’ язків у ролі помічника медичної сестри стаціонару 9 тижнів - по 2 тижні в терапевтичному і хірургічному, по 1 тижню в пологовому будинку в дитячому відділенні, по чотири дні на станції швидкої медичної допомоги та в кабінеті лікаря загальної практики і сімейної медицини та по одному дню в дитячій поліклініці й жіночій консультації. Зі студентів формуються 4 бригади по 14 студентів, котрі ротуються по відділеннях за заздалегідь розробленим планом, а до досвідчених фельдшерів, акушерок чи медсестр прикріплюється зазвичай по два студенти.

Студент фельдшер-акушер у результаті проходження переддипломної практики повинен володіти такими професійними навиками: ознайомитись і вміти вести медичну документацію в стаціонарі та кабінеті жіночої консультації; проводити опитування: зібрати скарги, загальний анамнез захворювання, акушерсько-гінекологічний та репродуктивний анамнез; виконувати необхідні медичні маніпуляції: вимірювання зовнішніх розмірів таза, висоти стояння дна матки та обводу живота; проведення зовнішнього акушерського обстеження, аускультації серцебиття плода, огляд шийки матки та піхви за допомогою піхвових дзеркал, володіти технікою бімануального дослідження, брати мазки з піхви на бактеріоскопічне (ступінь чистоти), гормональне та цитологічне дослідження, оформлення направлень у лабораторію; підготувати і скласти набір медичних інструментів для “великих” акушерських і гінекологічних операцій, пункції черевної порожнини через заднє склепіння піхви, діагностичного вишкрібання та оформлення направлення на гістологічне дослідження; проводити фізикальне обстеження хворих та аналізувати їх результати, планувати схему обстеження конкретного хворого та аналізувати результати основних лабораторних й інструментальних методів; визначати провідні патологічні симптоми і синдроми при найбільш поширених захворюваннях, проводити диференційну діагностику та встановлювати попередній діагноз найбільш поширених захворювань; брати участь у наданні невідкладної медичної допомоги при ургентних станах та надавати долікарську медичну допомогу; планувати тактику ведення вагітності, фізіологічних пологів та післяпологового періоду, визначати групи ризику вагітних, проводити бесіду на теми психопрофілактичної підготовки вагітних до пологів; проводити огляд та пальпацію грудних залоз, піхвові ванночки, спринцювання, вводити в піхву тампони із мазями, вагінальні супозиторії; вести фізіологічні пологи, проводити двомоментну обробку пуповини та первинний туалет новонародженого; встановлювати попередній діагноз ускладнень вагітності, пологів та післяпологового періоду, визначати терміни вагітності, терміни пологів, допологової та післяпологової відпусток; оволодіти морально-деонтологічними принципами медичного фахівця та принципами фахової субординації. Таким чином, формується професійна компетентність фельдшера-акушера, а самооцінка при виконанні основних практичних навичок може слугувати її мірилом.

Підсумковий контроль засвоєння практичних навичок, набутих під час виробничої практики, відбувається в останній день практики після їі завершення. Контроль проводиться керівниками переддипломної практики - викладачами від профільних кафедр на базі кафедри внутрішньої медицини та медсестринства № 2. На цій кафедрі $€$ аудиторії, котрі забезпечені манекенами та належними інструментами і “розхідними” матеріалами, необхідними для здачі практичних навичок з терапевтичного, хірургічного, педіатричного, акушерсько-гінекологічного профілів та невідкладної медичної допомоги. 
3 метою аналізу якості набуття професійної компетентності студентів з дисципліни “Акушерство та гінекологія” було проведено анонімне анкетування фельдшерів-акушерів після складання кафедрального диференційованого заліку та після проведення диференційованого заліку з оцінювання практики. В анкетуванні брали участь 60 студентів 4 курсу за спеціальністю “Лікувальна справа”.

Для характеристики якості набуття своїх практичних навичок 3 названої дисципліни фельдшериакушери проводили самооцінку за 5-бальною шкалою. Загальна тенденція є такою, що оцінка якості набуття своїх практичних навичок виявляється вищою після проведення диференційованого заліку 3 оцінювання практики за оцінку якості набутих практичних навичок після іспиту на кафедрі. На “задовільно” після кафедрального іспиту себе оцінювали 51,7 \% , на “добре” - 40 \% і лише 8,3 \% - на “відмінно”, але після проведення диференційованого заліку з оцінювання практики вже лише 35 \% оцінювали себе на “задовільно”, на “добре” - 50 \% і вже 15 \% - на “відмінно”, що певною мірою збігалося з реальними оцінками під час іспиту. Абсолютно чітко простежується тенденція: чим більш активна роль студента в проходженні виробничої практики, тим вища його самооцінка в набутті практичних навичок - зростає його професійна компетентність. Пояснення зі слів самих учасників опитування, отримані під час неформального спілкування, звучали приблизно так, що студент до кафедрального іспиту не мав достатньо часу, тому що “підтягував пропуски і недоліки”, отримані під час навчання, “прочитав і забув”. Відповіді після підсумкового контролю достовірно відрізнялися від пояснень, отриманих після кафедрального іспиту. Зі слів учасників опитування, їх самооцінка і засвоєння практичних навичок, набутих під час виробничої практики, значно покращились тому, що приходили практику в малих групах по двоє чи втрьох “закріплених” за досвідченими фельдшерами, акушерками чи медсестрами і “не знати було соромно”, а запам'ятовування практичного навику після побаченого чи виконаного самостійно під керівництвом досвідченого колеги, особливо декілька разів, закарбовується в свідомості і пам'яті набагато ефективніше і надовго.

\section{Список літератури}

1. Волкова Н. П. Педагогіка : навч. посіб. / Н. П. Волкова. - К. : Академвидав, 2007. - 616 с.
Головним документом фельдшерів-акушерів під час проходження переддипломної практики $є$ щоденник. Якість його ведення відображає ставлення майбутнього спеціаліста до медичної документації і переддипломної практики в цілому. Тільки 58,3 \% студентів відмічають, що ведуть щоденники щодня, 33,3 \% - щотижня, решта - наприкінці циклу. Серед фельдшерів-акушерів останньої підгрупи $є$ особи, які не бажають вести щоденники і “не бачать сенсу у цьому занятті”.

Дуже важливим є питання про плани випускників після закінчення коледжу продовжувати роботу за обраною спеціальністю. Більшість 91,6 \% фельдшерів-акушерів планують працювати в медицині, половина з них має намір продовжити освіту у вищому навчальному закладі. Не мають чіткого наміру продовження медичної діяльності і працювати далі за спеціальністю лише 8,4 \%. Головною причиною такого ставлення до медицини студенти відмічали соціальну незахищеність професії фельдшерів-акушерів і дуже низьку заробітну плату.

Зменшення тривалості роботи у відділеннях кожного профілю негативно відбивається на рівні опанування професійних навиків та вмінь. Важко набувати практичних медичних знань студентам за такий короткий проміжок часу, коли в перший день лише знайомляться з працівниками і роботою відділення, а через 3 дні чи вже і в перший і останній день вже необхідно підбивати підсумки. Теоретичні питання відображені у практичних навиках, якими має оволодіти студент.

Висновки. Залучення студентів-медиків до роботи на базах проходження виробничої практики дає можливість закріплення основних знань і умінь, опанувати необхідні медичні маніпуляції і навчитися технології їх проведення, а також раціонально оцінити результати своїх дій. Такий підхід до професійної підготовки майбутніх спеціалістів дає можливість підвищити їх компетентність у медичній сфері і готовність до виконання своїх фахових обов'язків.

Перспективним $є$ вивчення впливу відсутності переддипломної практики її впливу на професійну компетентності і “залишення в спеціальності” у випускників із спеціальністю “Сестринська справа” порівняно з випускниками коледжу із спеціальністю “Лікувальна справа”.

2. Особенности организации учебной и производственной практики студентов при переходе на 
образовательный стандарт нового поколения / Г. П. Гладилин, В. В. Якубенко, С. И. Веретенников, И. Л. Иваненко // Международный журнал экспериментального образования. - 2012. - № 10. - С. 79-80.

\section{References}

1. Volkova, N.P. (2007). Pedahohika: navchalnyi posibnyk [Pedagogy: a tutorial]. Kyiv: Akademvydav [in Ukrainian].

2. Gladilin, G.P., Yakubenko, V.V., Veretennikov, S.I., \& Ivanenko, I.L. (2012). Osobennosti organizatsii uchebnoy i proizvodstvennoy praktiky studentov pri perekhode na obrazovatelnyy standart novogo pokoleniya [Features of the organization of educational and industrial practice of students in the transition to the educational standard of the new generation]. Mezhdunarodnyy zhurnal eksperimentalnogo obrazovaniya - International Journal of Experimental Education, 10, 79-80 [in Russian].
3. Чорнобрива Н. В. Теоретичні засади підготовки майбутніх фельдшерів до професійної діяльності на засадах компетентнісного підходу / Н. В. Чорнобрива // Науковий вісник Чернівецького нац. ун-ту ім. Ю. Федьковича. Серія “Педагогіка та психологія”. - 2015. Вип. 987. - С. 135-142.

3. Chornobryva, N.V. (2015). Teoretychni zasady pidhotovky maibutnikh feldsheriv do profesiinoi diialnosti na zasadakh kompetentnisnoho pidkhodu [Theoretical principles of preparation of future Physician Assistant for professional activity on the basis of a competent approach]. Naukovyi visnyk Chernivetskoho natsionalnoho universytetu imeni Yuriia Fedkovycha. Seriia: Pedahohika ta psykholohiia Scientific Herald of Yuriy Fedkovych Chernivtsi National University. Series: Pedagogy and Psychology, 987, 135142 [in Ukrainian]. 